\title{
UNIVERSITY OF PENNSYLVANIA RADIOCARBON DATES IV
}

\author{
ELIZABETH K. RALPH and ROBERT E. ACKERMAN
}

Department of Physics and University Museum, University of Pennsylvania,

\author{
Philadelphia 4, Pennsylvania
}

With one exception, the radiocarbon dates in this list were reported previously by Rainey and Ralph (1959). For discussions of the reliability of the dates, of the materials dated, and of the correspondence of the dates with estimated arctic chronologies, the reader is urged to refer to the original publication. The radiocarbon determinations were made over a period of several years. Those processed before 1956 were dated by the solid-carbon method and are so labeled; others, by the carbon-dioxide method. The age calculations are based on the average of several samples dated archaeologically and by tree-rings, corrected to zero age (Rainey and Ralph, 1959, p. 365). By this means the errors due to atmospheric depletion (Suess effect) and to past changes in radiocarbon concentration (de Vries, 1958; Willis, Tauber, and Münnich, 1960) have been minimized. The B.P. dates are calculated from A.D. 1957 (solid-carbon) and A.D. 1958 (carbon dioxide).

The one exception, not included in the previous publication, is sample P-325 from St. Lawrence Island, Alaska (Okvik Period), a recount of C-505 (Chicago II) after conversion to carbon dioxide.

\section{Ekseavik Site series, Tree-Ring-Dated Samples}

Ekseavik site is along the Squirrel River, $8 \mathrm{mi} \mathrm{N}$ of the village of Kiana $\left(67^{\circ} 0^{\prime}\left(0^{\prime \prime} \mathrm{N}\right.\right.$ Lat, $160^{\circ} 41^{\prime} 18^{\prime \prime} \mathrm{W}$ Long), which is on the Kobuk River, Alaska. Coll. 1947 and subm. by J. L. Giddings, Brown University, Providence, Rhode Island. From the distribution of the dendrochronological dates, Giddings $(1952$, p. 107) states that house 11 was constructed between 578 and 568 B.P., occupied and rebuilt during the following two decades and abandoned after 548 B.P. As the bark dates are the crucial ones for the archaeologist rather than the average age of the wood used for dating, these $\mathrm{C}^{14}$ dates do not date the time of occupation of the site. These tree-ring-dated samples serve only as a check on the $\mathrm{C}^{14}$ dating.

P.16. Ekseavik, no. 42

$780 \pm 150$

Spruce wood from house 11, no. 42. Dated by tree-ring analysis, 874 to 571 B.P. Comment: dated by solid-carbon method, two counting runs.

P.29. Ekseavik, no. 33

$\mathbf{7 2 0} \pm \mathbf{2 0 0}$

Spruce wood from house 11, no. 33. Dated by tree-ring analysis, 738 to 593 в.1. Portion used for this measurement had an average of 691. Comment: dated by solid-carbon method.

P-31. Ekseavik, no. 1

$820 \pm 200$

Wood from house 11, no. 1. Dated by tree-ring analysis, 747 to 592 в.P. 
Portion used for this measurement had an average age of 688. Comment: dated by solid-carbon method.

\section{Kugusugaruk Site series}

Kugusugaruk site consists of a group of middens located $10 \mathrm{mi} \mathrm{S}$ of the village of Utkiavik (Barrow village) $\left(71^{\circ} 12^{\prime} \mathrm{N}\right.$ Lat, $156^{\circ} 30^{\prime} \mathrm{W}$ Long), Point Barrow, Alaska. Coll. 1917-1919 by W. B. Van Valin (deceased); subm. by F. Rainey, University Museum, University of Pennsylvania, Philadelphia. This site was incorrectly labeled "Utkiavik" by Rainey and Ralph (1959) as it was believed that Van Valin had worked at Utkiavik. Ford (1959, p. 19) revealed that Van Valin's site is actually Kugusugaruk. According to Ford's (p. 21, fig. 34) classification, the Kugusugaruk site burials fall in the early part of the Birnirk Period. Artifacts from this site are similar to those of the Birnirk site (Ford, 1959; Mason, 1930; Van Valin, 1941).

\section{P-73. Kugusugaruk (Birnirk Period), house $4 \quad 1430 \pm 190$}

Wood from a light-weight coarse-grained oval-shaped cylindrical piece, from house 4. (University Mus. no. 29-90-608). Broken end gives the impression of having been hafted in something. Comment: dated by solid-carbon method; individual dates of two portions are $1620 \pm 300$ and $1320 \pm 220$.

\section{P.97. Kugusugaruk (Birnirk Period) house $3 \quad 1146 \pm 95$}

Wooden meat tray (University Mus. no. 29-90-293) from house 3, found near skeleton no. 12 .

\section{P-55. Anderson Point Site}

$1130 \pm 200$

Spruce wood from the Anderson Point site on the Arctic Sea coast between Barter and Flaxman Islands $\left(70^{\circ} 02^{\prime} \mathrm{N}\right.$ Lat, $144^{\circ} 27^{\prime} \mathrm{W}$ Long), Alaska. Coll. 1952 by J. L. Giddings and A. Ricciardelli; subm. by J. L. Giddings, Brown University, Providence, Rhode Lsland., who noted that the material seemed roughly equivalent to Birnirk culture. Comment: dated by solid-carbon method; individual dates of two portions are $1160 \pm 240$ and $1090 \pm 310$.

\section{Kurigitavik Site series}

Kurigitavik site is located just back of the present village of Wales $\left(65^{\circ}\right.$ $36^{\prime} \mathrm{N}$ Lat, $168^{\circ} 4^{\prime} \mathrm{W}$ Long), Cape Prince of Wales, Alaska. Birnirk-type pottery occurs in the midden from about the middle to bottom levels. ThulePunuk harpoon heads occur from the surface of the midden to about the middle. Below the middle level the harpoon heads exhibit features suggestive of Birnirk. The one associated with sample P. 65 was the only typical Birnirk head found at the site (Collins, 1937a; 1940, p. 561-562). Coll. 1936 and subm. by H. B. Collins, Smithsonian Institution, Washington, D. C.

P-68. Kurigitavik (Thule-Punuk Period), 20 in. $1350 \pm 360$

Wooden dish (piece of base) and shafts (17 small pieces) from cut 2 , section 4, depth $20 \mathrm{in.}$ Comment: dated by the solid-carbon method.

P-67. Kurigitavik (Thule-Punuk Period), 29 in. $1230 \pm 240$

Wooden dish ( 2 pieces) from cut 6 , section 4 , depth 29 in. Typical Thule- 
Punuk harpoon heads and other artifacts occur at this level. Comment: dated by solid-carbon method.

\section{P-65. Kurigitavik (Birnirk Period), 88 and 90 in.}

$1320 \pm \mathbf{2 3 0}$

Wooden shafts (4 small pieces) from cut 3 , sections 20 and 21 , depth 88 and $90 \mathrm{in}$. (base). A Birnirk harpoon head was found in this cut at a depth of 86 in. Comment: dated by solid-carbon method.

\section{P-63. Beach Midden, Cape Prince of Wales}

$1480 \pm 240$

Wooden dish bottom from a large steeply sloping midden on a high beach located just south of the village of Wales $\left(65^{\circ} 36^{\prime} \mathrm{N}\right.$ Lat, $186^{\circ} 4^{\prime} \mathrm{W}$ Long), Cape Prince of Wales, Alaska. Sample is from cut A, section 26, depth 101 in. from near the base (upper part of slope). A Birnirk harpoon head was found in a nearby cut at about this level. The surface of the midden contains recent material (Collins, 1937a; 1940, p. 561-562). Comment: dated by solid-carbon method. This site was inadvertently placed under Kurigitavik site by Rainey and Ralph (1959).

\section{St. Lawrence Island series}

levoghiyoq. Miyowagh, and Hillside sites are located $\mathrm{E}$ of Gambell, near Cape Chibukak (63 $46^{\circ} 30^{\prime \prime} \mathrm{N}$ Lat. $171^{\circ} 43^{\prime} 20^{\prime \prime} \mathrm{W}$ Long), St. Lawrence Island, Alaska. Ievoghiyog and Miyowagh are situated on a gravel spit, and Hillside at the foot of Cape Chibukak.

\section{Ievoghiyoq Site}

Ievoghiyoq site is representative of the Punuk period (Collins, 1937b, p. 181-182). Coll. 1930 and subm. by H. B. Collins, Smithsonian Institution, Washington, D. C.

P-69. Ievoghiyoq (Punuk Period), no. $3549681070 \pm 210$

Wooden dish bottom (U. S. Nat. Mus. no. 354968) from cut 2, section 8, depth $52 \mathrm{in.}$ (hase). Comment: dated by solid-carbon method.

P-92. Ievoghiyoq (Punuk Period), no. 354971 $910 \pm 145$

Wooden object (U.S. Nat. Mus. no. 354971) from cut 2, section 8, depth 52 in. (base).

\section{Miyowagh Site}

Miyowagh is a two-level site containing cultural material from the Old Bering Sea Period and the early phase of the Punuk Period. In some instances (Collins' house 3). Punuk house floors have been dug into areas of the midden that vield predominantly Old Bering Sea artifacts. Samples P-83, P-85, P-88, P-84 and P-80 coll. and subm. by H. Michael. University Museum, University of Pennsylvania, Philadelphia.

P-83. Miyowagh (Early Punuk Period), shaft $1013 \pm 111$

Wooden shaft from test pit $18 \mathrm{~m} \mathrm{SW}$ by $\mathrm{S}$ of Collins' house 5 at depth $1.35 \mathrm{~m}$ below surface ( $2.5 \mathrm{~m}$ below house rim $)$. Coll. 1952 . 
P-85. Miyowagh (Late Old Bering Sea Period) $1002 \pm 108$

Wood from test pit $25 \mathrm{~m} \mathrm{~N}$ of NE corner of Collins' cut 26 from the 0.8 to $1.0 \mathrm{~m}$ level, in association with ivory harpoon point. Coll. 1952.

P-88. Miyowagh (Early Punuk Period), $\log \quad 1231 \pm 108$

Outer piece of large log found lying on flagstone floor of structure, Collins' house 3 entrance from 2.5-m level. Coll. 1952.

P-84. Miyowagh (Old Bering Sea Period), beam $1296 \pm 108$

Roof beam of passageway to house $4,1.4$ to $1.6 \mathrm{~m}$ level, in association with (OBS) whaling harpoon head. Coll. 1952.

P-80. Miyowagh (Old Bering Sea Period), wood $1398 \pm 116$

Piece of wood associated with OBS harpoon heads $0.8 \mathrm{~m}$ level, above P-88. Coll. 1952.

P-71. Miyowagh (Old Bering Sea Period), wood $1630 \pm 230$

Wooden ohjects, fire drills (U. S. Nat. Mus. nos. 353754 and 353769), from cut 7. levels 8 and 9, depths 46 and $51 \mathrm{in}$. Coll. 1930 and subm. by $\mathrm{H}$. B. Collins, Smithsonian Institution, Washington, D. C.

P-93. Miyowagh (Old Bering Sea Period), wood $1700 \pm 150$

Wooden objects (U.S. Nat. Mus. no. 353744) from cut 7, section 7, depth 37 in. Coll. 1930 and subm. by H. B. Collins, Smithsonian Institution, Washington, D. C.

\section{Hillside Site series}

Collins (1937b) originally designated the more simplified art style at the Hillside site "Old Bering Sea Style I." It was not until Rainey (1941) and Rudenko (1947) established Okvik as a distinct period that the "Old Bering Sea Style I" of Collins was recognized as a form of Okvik design. Collins, Giddings and Larsen (Ciddings, 1960, p. 123, 132, and 137) have considered Okvik to contain two to three separate art styles which may allow Okvik to be broken up into stages as has been done by Collins for Old Bering Sea. It has been assumed that Okvik preceded the Old Bering Sea Period. The following dates seemingly contradict this sequence. In light of continuing analyses of the Okvik and old Bering Sea culture. it has been noted by Levin (in Giddings, 1960) that the (Okvik and ()ld Bering Sea periods overlap. An early phase of ()ld Bering Sea culture could thus be older than a late phase of Okvik culture, giving rise to an apparent contradiction in the sequence hased upon single dates at some point in the culture's history rather than upon the total time span of the culture. Coll. 19:30 and subm. by H. B. Collins (except P-325), Smithsonian Institution, Washington, D. C.

P-95. Hillside (OId Bering Sea Period)

$1641 \pm 106$

Wooden objects (U. S. Nat. Mus. no. 352646) from house 1. Comment: 2 counting runs. 
P-70. Hillside (Okvik Period), no. $352547 \quad 1420 \pm 230$

Wooden object (U. S. Nat. Mus. no. 352547) from house 2, below floor stones. Comment: dated by solid-carbon method.

\section{P.94. Hillside (Okvik Period), no. $352558 \quad 1429 \pm 121$}

Wooden object (U. S. Nat. Mus. no. 352558) from house 2, below floor stones. Comment: two counting runs.

\section{P-325. Hillside (Okvik Period), Okvik house $1461 \pm 65$}

Carbon (Chicago solid-carbon sample C-505) derived from spruce log taken from Giddings' Okvik house (Rainey, 1941, p. 468-472). Coll. 1939 by J. L. Giddings, Brown University, Providence, Rhode Island; subm. to Chicago Laboratory 1951 by F. Rainey, Univ. Mus., Univ. of Pa. Carbon subm. in 1960 to Univ. of Pennsylvania laboratory by W. F. Libby, Institute of Geophysics, University of California, Los Angeles, and R. Ackerman, University of Pennsylvania, Philadelphia. Comment: Chicago solid-carbon date for this sample is $2258 \pm 230$ (Chicago II). The date for P-325 is in agreement with the other two Okvik samples listed here.

\section{P-98. Ipiutak Site, Point Hope $1619 \pm 210$}

Caribou antler from Ipiutak site, on the $\mathrm{N}$ shore of Point Hope Spit, ap. proximately $1 \mathrm{mi}$ from the village of Tigara $\left(68^{\circ} 19^{\prime} \mathrm{N}\right.$ Lat, $166^{\circ} 42^{\prime} \mathrm{W}$ Long). Point Hope, Alaska. The site extends $5 \mathrm{mi}$ or more to the east. Sample consisted of 14 caribou antler arrowheads, Type I, one of the most typical artifacts found at Ipiutak. Coll. 1948 and subm. by F. Rainey, Univ. Mus. U. of $\mathrm{Pa}$. This is the type site for the Ipiutak stage that $\mathrm{H}$. Larsen and $\mathrm{F}$. Rainey (1948) have described as the Paleo-Eskimo horizon in the arctic. Comment: other dates for Ipiutak culture are C-266, $912 \pm 170$, and C-260, $973 \pm 170$ (Chicago I).

\section{P-225. Cape Krusenstern Site}

$1651 \pm 130$

Charcoal from Cape Krusenstern site $\left(67^{\circ} 8^{\prime} 33^{\prime \prime} \mathrm{N}\right.$ Lat, $163^{\circ} 40^{\prime} 0^{\prime \prime} \mathrm{W}$ Long), located on a series of beach ridges between the villages or camp sites of Talikoot and Tikizat, Cape Krusenstern, Kotzebue Sound, Alaska. Coll. 1958 and subm. by J. L. Giddings, Brown University, Providence, Rhode Island. This is an extensive site of many cultural horizons that are located on a succession of beach ridges. Cultures earlier than Cape Denbigh Flint complex to the present are represented. This sample is representative of the Ipiutak period. Comment: sample was infested with rootlets which were removed as much as possible before processing.

\section{Native Point Sites series}

Native Point sites lie $40 \mathrm{mi} S$ of Coral Harbor $\left(64^{\circ} 10^{\prime} \mathrm{N}\right.$ Lat, $83^{\circ} 15^{\prime}$ W Long) on the SE coast of Southampton Island, Hudson`s Bay, Canada. Site $\mathrm{T} 1,1 \mathrm{mi} \mathrm{E}$ of the Sadlermiut site of Tunermiut, extends over 20 acres, covering most of a plateau $70 \mathrm{ft}$ high. T 3 site is $30 \mathrm{ft}$ lower than T 1 , on an old beach ridge, $40 \mathrm{ft}$ high, at the base of the T 1 plateau. Coll. 1954 and 1955 
and subm. by H. B. Collins, Smithsonian Institution, Washington, D. C. These are early Dorset period sites (Collins, 1956a, 1956b).

P-62. Native Point T 1 (Dorset Period), 14 in. $2060 \pm 200$

Charred bones from Test Pit 6 on the NE end of T 1 plateau, on a gravel ridge ca. $50 \mathrm{yd}$ from the Dorset midden. From a hearth 14 in. below the surface; hearth contained large quantities of burned mammal bones, blackened earth and gravel, and many bird bones. Comment: dated by solid-carbon method.

P.74. Native Point T 1 (Dorset Period), 12 in. $\quad 2183 \pm 122$

Burned bones, soil, and a few small pieces of charcoal from hearth area in T 1 site, Test Pit 8, from depth 12 in. (base).

P-75. Native Point T 1 (Dorset Period), 6 in. $\quad 2508 \pm 130$

Burned bones from T 1 site, trench A, square 1, level 2, depth 6 in. Trench A is 275 yards from Test Pit 8.

P-76. Native Point T 1 (Dorset Period), 6-10 in. $2632 \pm 128$

Burned bones from T 1 site, trench A, square 5 , levels 2 and 3, depth 6 to $10 \mathrm{in}$. Comment: on the basis of culture and stratigraphy, this sample is expected to be contemporaneous with P-75.

P-77. Native Point T 3 (Dorset Period), 8 in. $\quad 2191 \pm 120$

Burned bones from T 3 site, squares 1 and 9, level 2, depth 8 in. Comment: 2 counting runs.

\section{Yukon Island Site series}

Yukon Island is in Kachemak Bay, E of the city of Seldovia $\left(59^{\circ} 27^{\prime} \mathrm{N}\right.$ Lat, $151^{\circ} 44^{\prime} \mathrm{W}$ Long) on the Kenai Peninsula of Alaska. Coll. 1932 and subm. by F. de Laguna, Bryn Mawr College, Bryn Mawr, Pennsylvania. De Laguna (1934) defined 5 periods at this site which are described as Kachemak Bay I, II, III, Sub-III, and IV.

P-138. Kachemak Bay III Period, layers 6-9 $1369 \pm 102$ Caribou antler (5 pieces) from layers 6-9.

\section{P-139. Kachemak Bay I Period, layer 1}

Caribou antler (8 pieces) from level 1 , the earliest.

\section{Palugvik Site series}

Palugvik site is on the western spit of Hawkins Island $\left(60^{\circ} 30^{\prime} \mathrm{N}\right.$ Lat, $146^{\circ} 30^{\prime} \mathrm{W}$ Long). Prince William Sound, Alaska. The site is a large midden (onsisting of 4 layers; the bottom (no. 1 ) began in the Kachemak Bay III or sul-1ll period whereas the top layer (no. 4) indicates that the site was ahandoned before European contact (de Laguna, 1956). Coll. 1938 and subm. by de Laguna, Bryn Mawr College, Bryn Mawr, Pennsylvania. These samples represent the Kachemak Bay III Period. Comment: samples had been coated with paraffin. The suspicion that paraffin might have penetrated the wood was 
prompted by the date of a contaminated sample, a wooden shovel blade from the same site (P.173, $2265 \pm 112$ ), which should have been contemporaneous with P-174. The core of the house post (P.192) was therefore counted. The fact that the dates of P-192 and P-174 are in agreement indicates either that this post did not have serious paraffin contamination or that the paraffin was removed by the cleaning process.

P-174. Palugvik (Katchemak Bay III Period) $1753 \pm 105$

Wood from the outer part of house post (University Mus. no. 33-37-476).

P-192. Palugvik (Katchemak Bay III Period) $1727 \pm 105$

Wood from core of house post (University Mus. no. 33-37-476). The $\mathrm{C}^{14}$ date has been corrected for age of $83 \mathrm{yr}$ as determined by tree-ring count.

\section{Choris Site series}

Choris site is near the end of Choris Peninsula $166^{\circ} 16^{\prime} 24^{\prime \prime} \mathrm{N}$ Lat. $161^{\circ}$ $52^{\prime} 18^{\prime \prime} \mathrm{W}$ Long), Kotzebue Sound, Alaska. Coll. and subm. by J. L. Giddings. Brown University, Providence, Rhode Island. The site is considered by Giddings (1957) to contain artifacts typologically closer to Norton forms than to those of the Denbigh Flint complex. Comment: samples were broken into small pieces and visible rootlets removed before processing.

P-96. Choris Period, wood $2635 \pm 125$

Wood, a partially disintegrated base $\log$ heavily infused with rootlets, from Oval House 1. Coll. 1956.

\section{P-175. Choris Period, antler}

Worked fragments of antler (with a few rootlets) from floor deposit of Oval House 1. Coll. 1956.

\section{P-203. Choris Period, charcoal}

Charcoal from below roof level at $\mathrm{N}$ end of house 2 pit. Coll. 1958.

\section{P-228. Engigsteiak Site (Early Mountain Phase) $\quad 3208 \pm 156$}

Antler from Engigstciak site, located at foot of British Mountains, $16 \mathrm{mi}$ from the Arctic Ocean, on the E side of Firth River, about $0.5 \mathrm{mi} \mathrm{N}$ of where the narrow steep canyon of the Firth River gives way to a relatively wide valley that hecomes the Firth River Delta $\left(69^{\circ} 34^{\prime} 18^{\prime \prime} \mathrm{N}\right.$ Lat. $139^{\circ} 22^{\prime} 30^{\prime \prime} \mathrm{W}$ Iong). Yukon Territory, Canada. Sample from pit 32 (N. VK-1. S135W25). level 3-4, $1.7 \mathrm{ft}$ beneath ceramic's of Cordmarked and Dentate pottery. MacNeish, in a letter dated Oct. 6, 1958, stated that the culture typologically seems to be an early variant of Cape Denbigh. The site is described by MacNeish (1956). Coll. 1958 and suhm. by R. S. MacNeish. National Museum. Oltawa, Ontario. Canada.

\section{Igloolik Area series}

The 3 sites of Alarnerk, Kapuivik, and Kaleruserk are located in the area of Igloolik ( $69^{\circ} 10^{\prime} \mathrm{N}$ Lat, $83^{\circ} 59^{\prime} \mathrm{W}$ Long), Northwest Territory, Canada. Samples taken from house ruins found on raised gravel beaches. House ruins 
were found on various sites on terraces up to $54 \mathrm{~m}$ above present sealevel, revealing 3 distinct Eskimo cultures: Thule (5- to 8-m terraces), Dorset (8- to 22-m terraces), and Sarqaq (23- to 54-m terraces) (Meldgaard, 1960). Coll. 1954 and 1957 and subm. by Jørgen Meldgaard, Danish National Museum, Copenhagen. Denmark. Comment: the dates for antler samples are consistently younger than those for ivory. Ivory is believed to he a more reliable material.

\section{P-212. Alarnerk (Dorset Period, Stage I), antler}

$2404 \pm 137$

Antler from $22 \mathrm{~m}$ above sealevel. Comment: compare with P-213.

P-213. Alarnerk (Dorset Period, Stage I), ivory $2910 \pm 129$

Ivory from $22 \mathrm{~m}$ above sealevel.

P-211. Kapuivik (Late Sarqaq Period), antler $2354 \pm 135$

Antler from $24 \mathrm{~m}$ above sealevel.

P.210. Kapuivik (Early Sarqaq Period), antler $2898 \pm 136$

Antler from $44 \mathrm{~m}$ above sealevel.

P-208. Kaleruserk (Early Sarqaq Period), antler

$3560 \pm 123$

Antler from $51 \mathrm{~m}$ above sealevel. Comment: this sample is identical to K-505, $3700 \pm 300$ (Copenhagen IV) ; compare also with P-209.

P-209. Kaleruserk (Early Sarqaq Period), ivory, $51 \mathrm{~m}$

Ivory from $51 \mathrm{~m}$ above sealevel.

P-207. Kaleruserk (Early Sarqaq Period), ivory, $52 \mathrm{~m}$

Ivory from $52 \mathrm{~m}$ above sealevel.

$3958 \pm 168$

\section{Iyatayet Site series}

Iyatayet site is on the $\mathbb{W}$ side of Cape Denbigh $\left(64^{\circ} 25^{\prime} 42^{\prime \prime} \mathrm{N}\right.$ Lat, $161^{\circ}$ $31^{\prime} 30^{\prime \prime}$ W Long), on steep slopes flanking a fresh-water stream, Norton Sound. Alaska. Coll. 1948-1950 and subm. by J. L. Giddings, Brown Univ., Providence, R. I. There are three cultural levels at Iyatayet, an upper Neo-Eskimo (Nuklet), a middle Paleo-Eskimo (Norton culture), and a separated lower level defined as the Denbigh Flint complex (Giddings, 1949). Charcoal samples from the very thin layer of Denbigh Flint material were contaminated with roots of later date which were probably not removed successfully before processing. David Hopkins of the U. S. Geol. Survey, who made a study of this site, believed that geologic, paleobotanical, and radiocarbon evidence all point to an age of more than 5000 and less than $10,000 \mathrm{yr}$ (Giddings, 1955).

\section{P-13. Norton Culture (Paleo-Eskimo)}

$2213 \pm 110$

Charcoal from baseline timbers of $\mathbb{W}$ wall. Comment: this was a new portion of the same material as that used for C-563 (Chicago II), dated $2016 \pm$ 250 in 1951. Another portion of P-13 was dated by solid-carbon method, 
average of 3 counting runs is $2360 \pm 170$. Compare also with C.506 (Chicago I), $1460 \pm 200$.

P-104. Above Denbigh Complex, sec. IYZ-5B $3000 \pm 170$

Peat and earth from second peat above Denbigh Flint complex, section IYZ-5B. Comment: dated by solid-carbon method; 3 counting runs. C-793 (Chicago IV), $3509 \pm 230$, was taken from the same section.

P-108. Above Denbigh Complex, sec. IYZ-5A $3080 \pm 210$

Dry peat and earth from peaty layer next above Denbigh Flint complex, section IYZ-5A. Comment: dated by solid-carbon method; 2 counting runs.

\section{P-105. Denbigh Complex, sec. IYZ-5B $\quad 4040 \pm 280$}

Charcoal mixed with earth from soil above Denbigh Flint complex, but below peaty layer where peaty layer was covered with sterile sandy layer, section IYZ-5B. Comment: dated by solid-carbon method. Sample contaminated with roots.

P-103. Denbigh Complex, sec. IYZ-5D

$3480 \pm 200$

Charcoal and charred twigs from 2 fireplaces, section IYZ-5D. Comment: dated by solid-carbon method, 2 counting runs. Sample contaminated with roots.

P-102. Denbigh Complex, sec. IYR

$3310 \pm 200$

Charcoal, earth, and a few roots from fireplace from section IYR. Comment: dated by solid-carbon method; 2 counting runs. Compare this sample and P.105 and P.103 with C-793 (Chicago IV), $4658 \pm 220$ and with W-298 (USGS III), $3970 \pm 600$. Sample contaminated with roots.

GENERAL COMMENT

Dates obtained by the CO.2 method are considered more reliable than those obtained by the solid-carbon method, and thus we have placed our major emphasis on those dates. One date worthy of comment, and not previously listed in the paper by Rainey and Ralph (1959), is P-325 from the Hillside site at Cambell, St. Lawrence Island. Alaska. Dated by the solid-carbon method (C-505, $2258 \pm 30$, Chicago II). this sample was used by Giddings (1960, p. 123) as a basal date for the cultural sequence on St. Lawrence Island. The new date for this sample $(1461 \pm 65)$ by the $\mathrm{CO}_{2}$ dating process places the Okvik house excavated by Giddings at Gambell within the time period of the Old Bering Sea culture. New samples are yet necessary for a firm dating of the Okvik culture in the Bering Sea region and until they are obtained, the claim of precedence for the Okvik culture will necessarily have to rest upon archaeological interpretation.

A tentative cultural chronology for the Arctic was attempted previously (Rainey and Ralph, 1959, p. 373) and found to be useful. This chronologic sequence reproduced below is, however, to be used with caution as it is for the most part hased on too few samples. 
Neo-Eskimo Horizon

Punuk Period

Birnirk

Kachemak Bay III Period

A.D. 1000

Okvik Period

A.D. 800

A.D. 600

Old Bering Sea Period

A.D. 500

t.D. 300

Paleo-Eskimo Horizon

Ipiutak Period

A.D. 300

Norton Period

300 B.C

Dorset Period

Kachemak Bay I Period

200 to 700 B.c.

Choris Period

700 B.C.

700 B.C.

Ancient Arctic Horizon

Firth River

\section{Sarqaq}

(Early Mountain Phase)

1300 B.c.

Jenbigh Flint Complex

400 to 2000 B.C.

Earlier than 2000 B.C.

Date lists:

REFERFNCES

$\begin{array}{ll}\text { Chicago I. } & \text { Arnold and Libby, } 1951 \\ \text { Chicago II. } & \text { Libby, 1951 } \\ \text { Chicago IV. } & \text { Libby, 1954 } \\ \text { Copenhagen IV. } & \text { Tauber, 1960 } \\ \text { USGS III. } & \text { Rubin and Suess, } 1956\end{array}$

Arnold, J. R., and Libby, W. F., 1951, Radiocarbon dates: Science, v. 113, p. 111-120.

Collins, H. B., Jr., 1937a, Archaeological excavation at Bering Strait: Smithsonian Inst. 1936 Explor, and Field Work, p. 63-74.

1937b, Archaeology of St. Lawrence Island, Alaska: Smithsonian Misc. Coll., v. 96 , no. 1,431 p.

1940, Outline of Eskimo prehistory: Smithsonian Misc. Coll., v, 100, p. 533-592.

1956a, The T 1 site at Native Point, Southampton Island, N.W.T.: Alaska Univ. Anthropol. Papers, v. 4, no. 2, p. 63-89.

1956b, Archaeological investigations on Southampton and Coats Island, N.W.T. Canada Nat. Mus. Ann. Rept., 1954-55, Bull. 142, p. 82-113.

Ford, J. A., 1959, Eskimo prehistory in the vicinity of Point Barrow, Alaska: Am. Mus. Nat. History Anthropol. Papers, v. 47, pt. 1, p. 19-21.

Giddings, J. L., 1949, Early flint horizons on the North Bering Sea coast: Washington Acad. Sci. Jour., v. 39 , no. 3 , p. 85.90

1952, The arctic woodland culture of the Kobuk River: Philadelphia, Univ. Mus., Univ, of Pennsylvania, Museum Monographs, ix, 143 p.

1955, The Denbigh Flint complex is not yet dated: Am Antiquity, v, 20, no. 4, p. $375-376$.

135. 1957, Round houses in the western arctic: Am. Antiquity, v. 23, no. 2, p. 1211960, The archaeology of Bering Strait: Current Anthropology, v. 1, no. 2, p. 121-138.

Laguna, Frederica de, 1934, The archaeology of Cook Inlet, Alaska: Philadelphia, Univ. of Pennsylvania Press, 263 p.

1956, Chugach prehistory; Washington Univ. [Seattle], Pub. in Anthropology, v. 13 , xix, $289 \mathrm{p}$.

Larsen, Helge, and Rainey, Froelich, 1948, Ipiutak and the arctic whale hunting culture: Am. Mus. Nat. History Anthropol. Papers, v. 42, 276 p.

Libby, W. F., 1951, Radiocarbon dates II : Science, v. 114, p. 291-296

1954, Chicago radiocarbon dates IV: Science, v. 119, p. 135-140.

MacNeish, R. S., 1956, The Engigstciak site on the Yukon arctic coast: Alaska Univ. Anthropol. Papers, v. 4, no. 2, p. 91-112. 
Mason, J. A., 1930, Excavations of Eskimo Thule culture sites at Point Barrow, Alaska: Internat. Cong. Americanists, 23d, New York 1928, Proc., p. 383-394.

Meldgaard, Jørgen, 1960, Origin and evolution of Eskimo cultures in the eastern arctic: Canadian Geog. Jour., v. 60, no. 2, p. 64-75.

Rainey, Froelich, 1941, Eskimo prehistory: The Okvik site on the Punuk Islands: Am. Mus. Nat. History Anthropol. Papers, r. 37, pt. 4, p. 453-569.

Rainey, Froelich, and Ralph, Elizabeth, 1959, Radiocarbon dating in the arctic: Am. Antiquity, v. 24 , no. 4, p. $365-374$.

Rubin, Meyer, and Suess, H. E., 1956, U. S. Geological Survey radiocarbon dates III: Science, r. 123 , p. $442-448$.

Rudenko, S. I., 1947. Drevniia kul'tura Beringova moria i Eskimosskaia problema [Ancient culture of the Bering Sea region and the Eskimo problems]: Moscow and Leningrad, Glav-Ser-Mor-Put Press, 135 p.

Tauber, Henrik, 1960, Copenhagen radiocarbon dates IV: Am. Jour. Sci. Radioc. Supp., v. $2,1,12-25$.

Van Valin, W. B., 1941. Eskimo land speaks: Caldwell, Idaho, Caxton Printers Ltd., p. $227-238$.

Vries, Hessel de. 1958, Variation in concentration of radiocarbon with time and location on Earth: Koninkl Nederlandse Akad. Wetensch. Proc., ser. B, v. 6l, no. 2, p. 1-9.

Willis, E. H., Tauber, Henrik, and Münnich, K. O., 1960, Variations in the atmospheric radiocarbon concentration over the past 1300 years: Am. Jour. Sci. Radioc. Supp., v. 2 , p. 1.4 . 